\section{Fibrosarcoma in the nasal cavity of a donkey}

\author{
Fibrossarcoma na cavidade nasal de um muar
}

\begin{abstract}
Iolanda Gea Kassem*, Natalia Bernstein', Paula Rodrigues Lopes², Patrícia de Castro Duarte², Matheus Vilardo Lóes Moreira² ${ }^{2}$ Fernanda Guimarães Miranda² , Anelise Carvalho Nepomuceno³ Renata de Pino Albuquerque Maranhão ${ }^{4}$, Roselene $\mathrm{Ecco}^{4}$ \& Maristela Silveira Palhares ${ }^{3}$
\end{abstract}

'Veterinarians. Escola de Veterinária - EV, Universidade Federal de Minas Gerais - UFMG, Belo Horizonte, MG, Brasil Veterinarians, MSc. Escola de Veterinária - EV, Universidade Federal de Minas Gerais - UFMG, Belo Horizonte, MG, Brasil ${ }^{3}$ Veterinarians, Dr. Departamento de Clínica e Cirurgia Veterinárias, Escola de Veterinária - EV, Universidade Federal de Minas Gerais - UFMG, Belo Horizonte, MG, Brasil

${ }^{4}$ Veterinarians, Dr., Post doctorate. Departamento de Clínica e Cirurgia Veterinárias, Escola de Veterinária - EV, Universidade Federal de Minas Gerais - UFMG, Belo Horizonte, MG, Brasil

\begin{abstract}
Clinical and pathological findings in a case of malignant tumor located in the nasal and paranasal sinuses of a six-year-old donkey are reported. The animal was referred to the Equine Veterinary Hospital after three years of progressively increasing facial swelling. Clinically, the animal presented with tachypnea, dyspnea, and wheezing in the laryngotracheal region. There was swelling in the frontal bone and left orbital regions with exophthalmos of the left eye and bilateral mucopurulent nasal discharge, as well as retropharyngeal lymph node enlargement. Radiographic examination revealed radiopacity in the left maxillary, frontal and nasal sinuses, and in the left orbital region. Endoscopy revealed an irregular mass in the nasopharynx. Computed tomographic images of the skull showed an irregular mass, of variable density, in the rostral region, extending from the nasal cavity to the conchofrontal sinus on the left side, with dorsal displacement of the septum and dorsal nasal meatus. Loss of definition and destruction of other osseous structures of the nasal cavity and the frontal bone, and hypodense areas at the encephalic periphery were evident. Computed tomographic scans were taken to identify the localization and extension of the mass. Fibrosarcoma was confirmed on the histopathological examination for the first time in this species. The tomographic scan was considered more effective than radiography.
\end{abstract}

Keywords: skull, equine, histopathology, neoplasia, sinonasal cavities, tomography.

\section{Resumo}

Relata-se os achados clínicos, imaginológicos e patológicos em um muar de seis anos de idade com neoformação tecidual na região de seios nasais e paranasais. O paciente fora encaminhado ao Hospital Veterinário de equinos após três anos de progressão. Clinicamente, o animal demonstrava taquipneia, dispneia e alteração do ruído laringotraqueal. Observou-se aumento de volume no osso frontal e na região orbitária esquerda, acompanhado de exoftalmia do bulbo ocular ipsilateral, além de secreção nasal mucopurulenta bilateral. Os linfonodos retrofaríngeos estavam reativos. Ao exame radiográfico, foi constatado aumento da radiopacidade na região de seios maxilar, frontal, nasal e orbitário esquerdos. A tomografia computadorizada do crânio evidenciou uma massa tecidual de contorno irregular com densidade variável da região rostral da cavidade nasal até o seio conchofrontal esquerdo, com deslocamento do septo e do meato nasal dorsal. Além disso, ocorreu perda de definição e destruição das demais estruturas ósseas da cavidade nasal e do osso frontal, além de áreas hipodensas na periferia encefálica. Ao exame histopatológico, diagnosticou-se fibrossarcoma, pela primeira vez documentado na espécie. O exame tomográfico mostrou-se mais acurado quanto à extensão da lesão quando comparado ao exame radiográfico na cavidade nasal.

Palavras-chave: crânio, equídeo, histopatologia, neoplasia, seios nasais, tomografia.

\section{Introduction}

Tumors in the nasal and paranasal sinuses have rarely been reported in horses while in donkeys, to our knowledge, no case has been reported in the literature. In 1973, squamous cell carcinoma in the frontal sinus and nasal cavity was reported in two horses from southeastern Brazil (Alvarez et al.,1973). In 2012, a case of sinus carcinoma was described in an equine in Minas Gerais (Silva et al., 2012). In the United States, Boulton (1985) reported the incidence of neoplasia as 19\% among 85 cases of alterations in the nasal and paranasal cavities, over a period of eight
How to cite: Kassem, I. G., Bernstein, N., Lopes, P. R., Duarte, P. C., Moreira, M. V. L., Miranda, F. G., Nepomuceno, A. C., Maranhão, R. P. A. Ecco, R., \& Palhares, M. S. (2018). Fibrosarcoma in the nasal cavity of a donkey. Brazilian Journal of Veterinary Medicine, 40, e96018. doi: 10.29374/2527-2179.bjvm096018

\section{Financial support: None.}

Conflict of interests: No conflict of interests declared concerning the publication of this article.

Received: May 28, 2018.

Accepted: July 05, 2018.

The study was carried out at Universidade Federal de Minas Gerais - UFMG, Belo Horizonte, MG, Brasil.

\section{*Correspondence}

Iolanda Gea Kassem

Escola de Veterinária - EV, Universidade

Federal de Minas Gerais - UFMG

Avenida Antônio Carlos, 6627, Campus

Pampulha, Caixa Postal 567

CEP 31270-901 - Belo Horizonte (MG), Brasil

E-mail: sonoequi@outlook.com 
years. In Scotland, of 277 cases with sinus disorders described between 1984 and 1996, 7.9\% were diagnosed as neoplasia (Tremaine \& Dixon, 2001).

The most commonly diagnosed neoplasias are carcinoma, fibrosarcoma, myxoma, and osteoma; squamous cell carcinoma is the most common (Boulton, 1985; Witte \& Perkins, 2011; Cissell et al., 2012). The occurrence of neoplasia shows no correlation with sex or race, but neoplastic processes occur more frequently in horses older than 10 years. However, cases such as leiomyosarcoma in a two-year-old equine and fibrosarcoma in a nine-year-old Appaloosa mare have been reported (Dixon \& Head, 1999; Veraa et al., 2009). Fibrosarcoma has also been described in the reproductive tract of a donkey (Bonfig \& Ingenhorst, 1992).

The initial clinical signs of sinus neoplasia are easily confused with those of local inflammatory disease and are related to the size, location, and growth pattern of the neoplasia (Witte \& Perkins, 2011).

The diagnosis of head lesions in equines is challenging for the veterinarian, because this region contains multiple overlapping structures of different tissue densities. Thus, the use of the imaging technology becomes important for identifying the degree of extension of the alteration, in association with the histopathological examination that will provide the definitive diagnosis (Manso-Díaz et al., 2015).

Radiographic examination is the most commonly performed procedure. However, its interpretation may be erroneous due to the overlap of anatomical structures in the imaged regions (Manso-Díaz et al., 2015). Computed tomography (CT) is based on obtaining several sections of the region of interest, without overlapping of structures, which makes possible a higher degree of soft-tissue contrast and reconstruction of the image in other planes (Veraa et al., 2009).

The objective of the present report is to describe the clinical, imaging, and pathological findings of a neoplasia in the nasal cavity of a donkey.

\section{Historical findings}

A six-year-old female donkey was referred to the Equine Clinic of the Veterinary School of the Federal University of Minas Gerais (EV-UFMG), with a complaint of progressive increase in the face region for approximately three years. Previous attempts at treatment included topical application of iodized solution and an attempt to drain the contents, both without success. With the worsening of the clinical symptoms, it was decided to refer the donkey to the hospital.

During clinical examination, facial asymmetry was observed, with increased volume in the left orbital region and frontal bone, causing exophthalmos of the ipsilateral eye, as well as bilateral mucopurulent nasal secretions (Figure1). The patient had a noisy wheezing in the laryngotracheal region, enlarged retropharyngeal lymph nodes, tachypnea, and dyspnea. Complete obstruction of the left nostril and absence of direct and consensual pupillary reflex in the left eye were noted. In order to improve the patient's breathing pattern during the hospitalization period, a tracheostomy was performed.

Radiographic examination of the skull showed a volume increase and radiopacity with variable density in the nasal cavity, and in the maxillary, frontal and left orbital sinuses (Figure 2).

Faced with an initial diagnostic suspicion of malignant neoplasia and the severity of the clinical symptoms, the owner chose to perform euthanasia. With the objective of scientific documentation and better delimitation of the neoplasia, a tomographic examination of the skull was performed immediately. Images were acquired using an axial device, Siemens Somaton ART ${ }^{\circledR}$, in transverse, longitudinal, and dorsal 5-millimeters thick planes, from the rostral region of the nasal cavity to the atlanto-occipital joint. Irregularly contoured tissue mass of variable density, hyperdense (167 UH) and hypodense (35 UH) areas, extending from the rostral region of the left nasal cavity to the left conchofrontal sinus, was observed. There was lateral displacement of the nasal septum and dorsal nasal meatus, loss of definition and destruction of the other osseous structures of the nasal cavity and frontal bone, impairment of the masseter and buccinator muscles, as well as left exophthalmia (Figure 3). Hypodense areas (-800 UH) were observed in the periphery of the brain (pneumocephalus) without destruction of the cranial bones.

Necropsy confirmed tomographic findings of neoplasia in the nasal cavity with lateral displacement of the nasal sinus (Figure 4). 


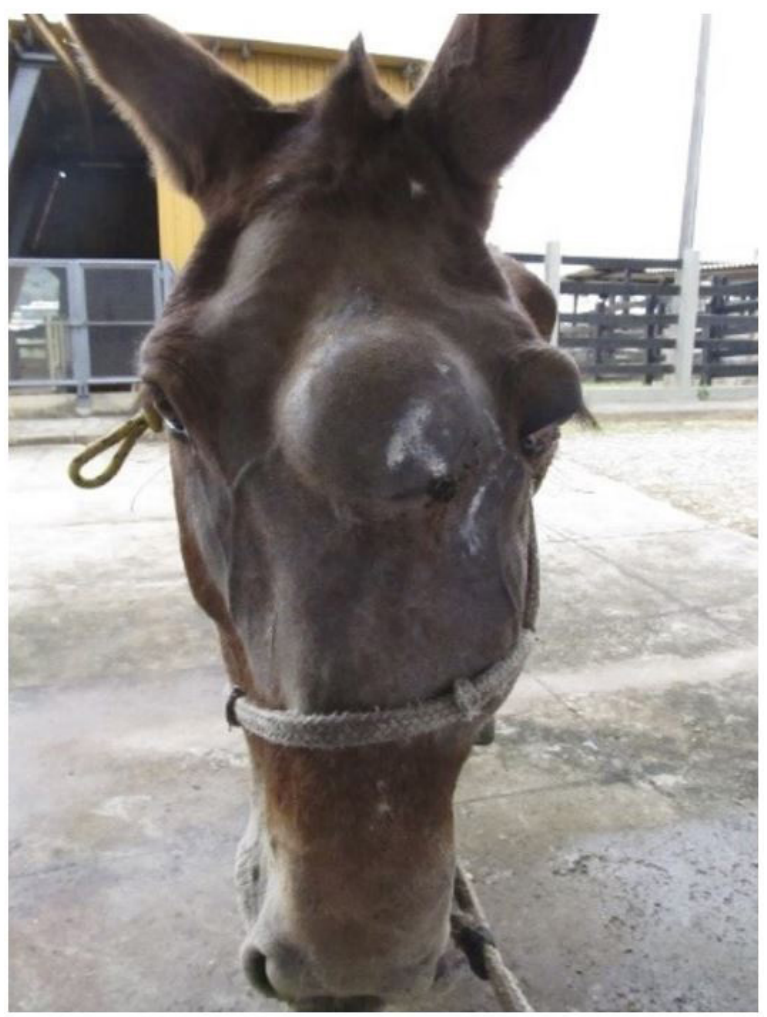

Figure 1. Clinical presentation of the facial region of a six-year-old donkey. Centrally, there is a nodular mass between the orbits, as well as facial asymmetry, with enlargement of the frontal and nasal bones, causing exophthalmos of the ipsilateral eye.

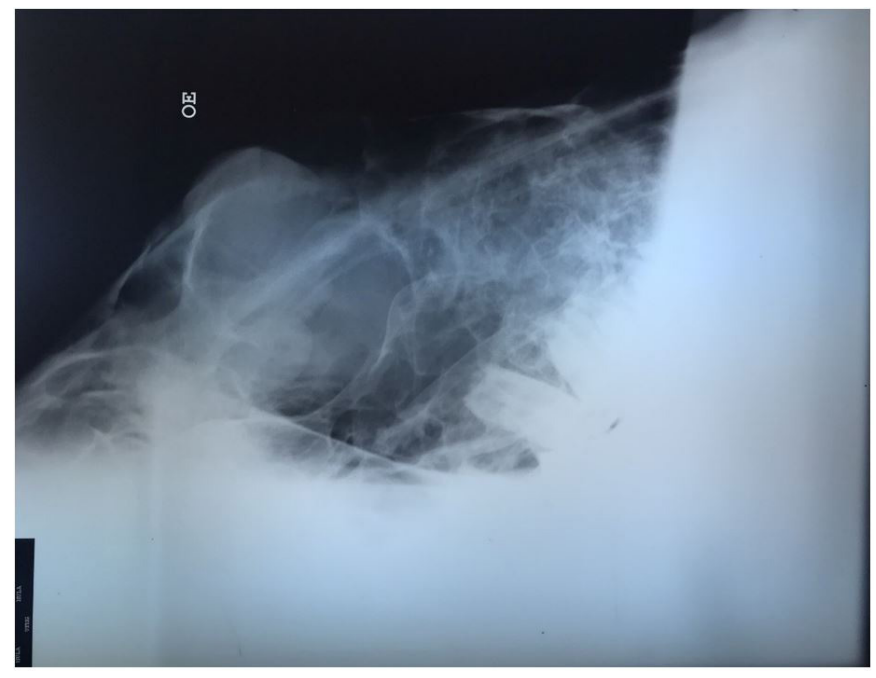

Figure 2. Radiographic examination in left lateral oblique projection of the skull of a six-year-old donkey. An increase in volume and of radiopacity with variable density in the nasal cavity, and in the maxillary sinuses, frontal region, and left orbit can be seen.

Proliferation was infiltrative and, in addition to compressing and replacing adjacent tissues, had led to partial loss of the left nasal and orbital bones. Histopathological examination revealed a dense neoplastic proliferation of mesenchymal cells; the tumor mass was non-encapsulated, infiltrative, forming intertwined bundles in multiple directions, and sustained by a notable amount of fibrovascular tissue. The cells were predominantly spindle-shaped, some oval, with eosinophilic 


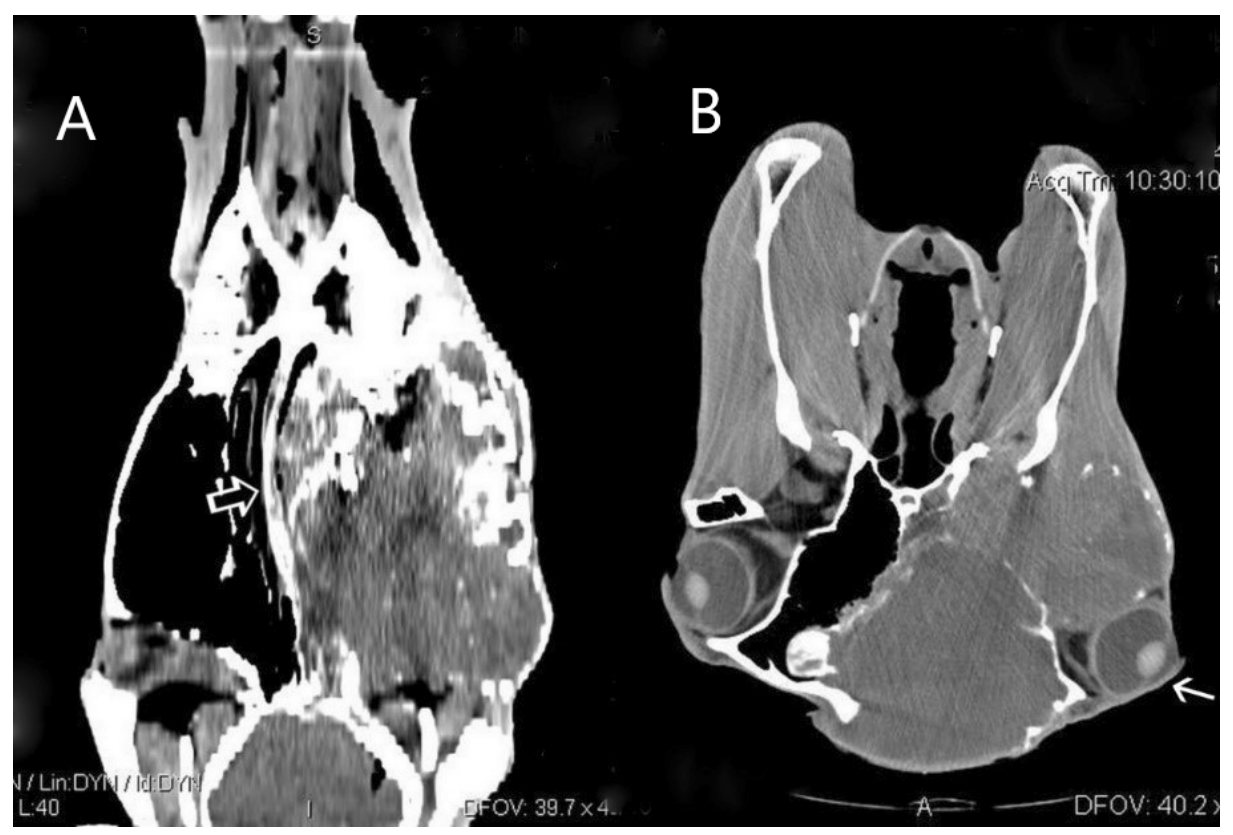

Figure 3. Tomographic examination of a six-year-old donkey. (A) Longitudinal multiplane reconstruction, soft-tissue window: irregular, heterogeneously contoured mass, extending from the rostral region of the left nasal cavity to the left conchofrontal sinus. There is displacement of the nasal septum to the right (arrow), with loss of definition and destruction of the other osseous structures of the nasal cavity; (B) Tomographic image in cross-section, in a soft-tissue window in which left exophthalmia (arrow) and adjacent soft tissue impairment are visualized.

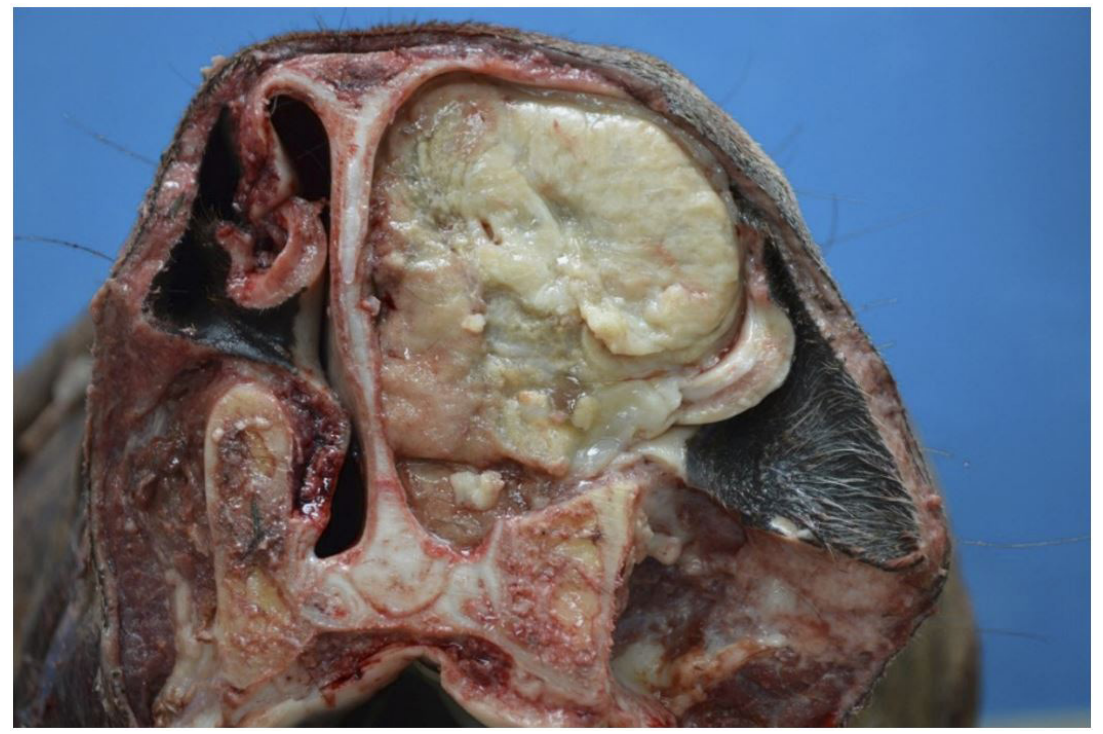

Figure 4. Rostral cross-sectional view of the bone and nasal cavity of the subject. A solid, white neoplasm, replacing the nasal turbinates, filling and obstructing the left nasal cavity, with displacement of the nasal septum to the right, is observed.

cytoplasm and very imprecise cytoplasmic boundaries. The nuclei were oval to fusiform, with loose chromatin and 1 to 3 prominent nucleoli. There were eight mitoses in 10 fields of highest magnification (x400) (Figure 5A, B, and C). Interspersed with the neoplasia were some areas with hemorrhage, necrosis, and mineralization. The neoplasia had infiltrated and destroyed the tissue of the nasal conchae and adjacent bone. Histochemistry was performed using Masson's Trichrome that marked the cytoplasm of neoplastic cells in blue (Figure 5D). 


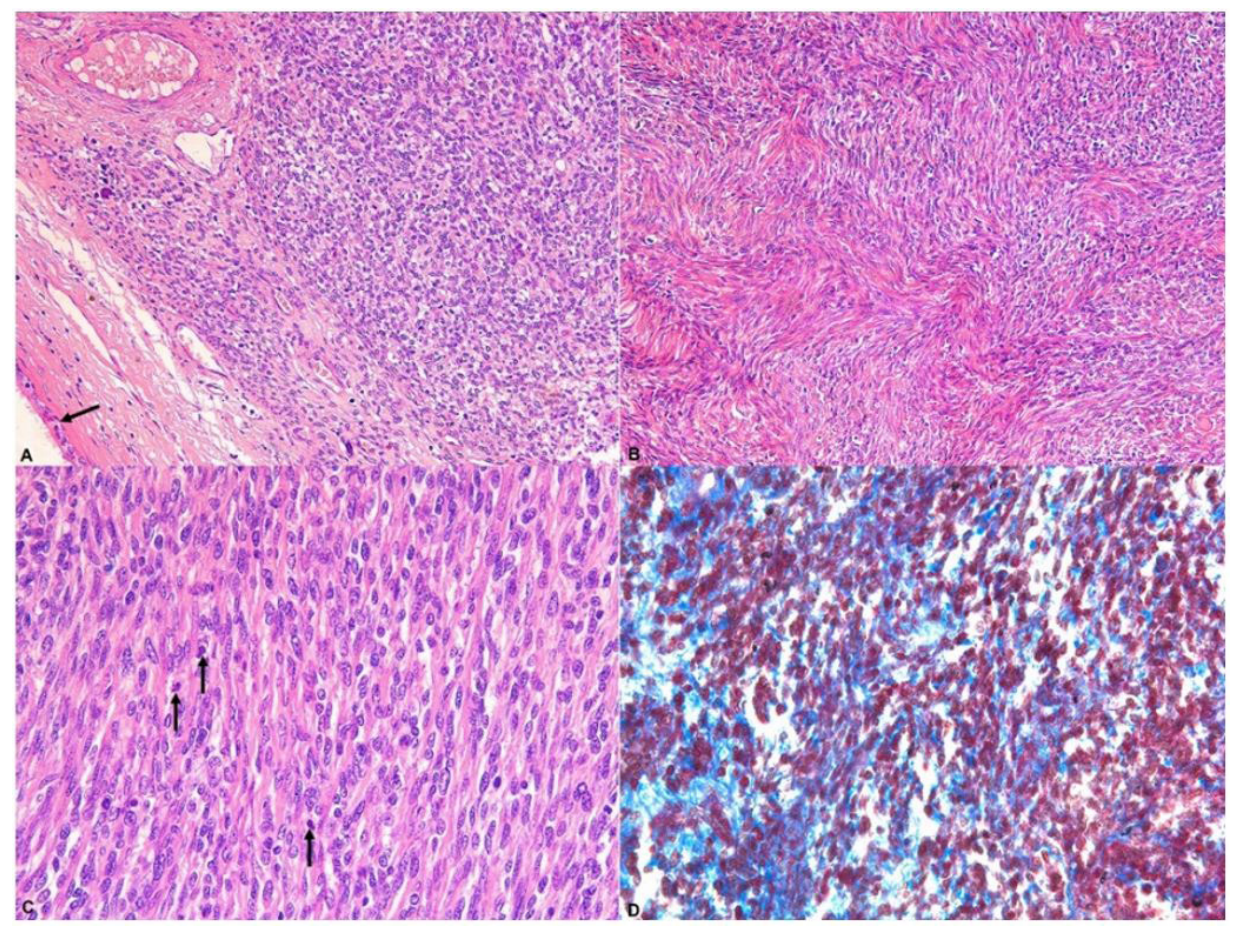

Figure 5. Histopathology of nasal neoplasm. (A) Infiltrative mesenchymal cells, arranged in solid bundles, close to the respiratory epithelium (arrow). Hematoxylin and eosin (H\&E) staining, x200; (B) Infiltrative mesenchymal cells, arranged in solid bundles along multiple axes. H\&E, x2O0; (C) Larger increase of proliferation shown in figure A and B. Spindle shaped mesenchymal cells, with eosinophilic cytoplasm and very imprecise cytoplasmic boundaries. The nuclei are spindle-shaped, with widely distributed chromatin, and 1 to 3 prominent nucleoli. Note some mitosis figures (arrows). H\&E, x400; (D) Neoplastic proliferation of mesenchymal cells containing cytoplasm stained blue with Masson's Trichrome, x400.

\section{Discussion}

The presenting clinical symptoms of the animal - facial volume increase, nasal discharge, rhinodyspnea, and epistaxis - led to the suspicion of a tissue mass involving the upper respiratory tract, based on the extant reported literature. As differential diagnoses, ethmoidal hematoma, sinusitis, fractures, and alveolitis have been suggested (Tremaine \& Dixon, 2001; Veraa et al., 2009). According to Head \& Dixon (1999), expansive and infiltrative tumors can destroy the bones of the dorsal and ethmoid shell and cause remodeling and enlargement of the face. This may progress to invasion of the orbital region by the mass arising from the frontal, ethmoidal, or maxillary sinuses, with consequent exophthalmos.

Radiographic images did not provide details of the type and location of the tumor, as were obtained by the computerized tomography (CT) images, only changes in the radiopacity of the mass, without exact delimitation of the affected region. Some authors have reported the difficulty of determining the degree of mass extension, as well as the impairment of adjacent tissues using radiography alone (Solano \& Brawer, 2004; Bass et al., 2017).

The most commonly found radiological alterations are bone distortion, especially in the frontal and maxillary bones, or areas with soft tissue density. In some cases, the involvement of periodontal structures may also be observed (Tremaine \& Dixon, 2001; Silva et al., 2012). However, radiographic findings underestimate the severity of bone impairment adjacent to the mass, which CT images evidence (Cissell et al., 2012).

Due to the superiority of CT in relation to radiography, the former could help in the elaboration of a diagnostic or therapeutic plan, such as biopsies or future surgical intervention (Manso-Díaz et al., 2015). 
In the CT performed in this study, mass images with muscle tissue density (35-50 UH) were obtained, with areas of mineralization, explaining the variation in density, in contrast to the reference images of the study by El-Gendy et al. (2014), where the sinuses were seen as air-filled, well-defined spaces.

Malignant neoplasms tend to cause moderate-to-severe lysis of the cortical bone layer and the appearance of the mass varies according to the origin of the neoplasia. Most have a relatively homogeneous soft-tissue appearance, except for ossified fibroids. The incidence of fibrosarcoma in equines is low, at 1.9\%, and usually affects the mandibular region, as reported in a retrospective study of 536 neoplasms in horses in the United States (Valentine, 2006).

Fibrosarcoma is characterized by its grayish appearance, firm consistency, and lobulated shape, along with poorly defined margins surrounded by necrosis and hemorrhage (Valentine, 2006). The tumor reported in this study had a white coloration and filled the entire left nasal cavity of the animal, causing a displacement of the nasal septum to the opposite side.

The histopathological findings are in agreement with those found in the cases described by Bass et al. (2017), with the presence of infiltrative mesenchymal cells arranged along multiple axes.

The early identification of the neoplasia is important for the establishment of a therapeutic protocol as well as informing its prognosis. The combination of imaging and mass biopsy offers great potential for minimally invasive evaluation, allowing the veterinarian to reach an early diagnosis with therapeutic options (Witte \& Perkins, 2011; Cissell et al., 2012). However, in the present report, the history of progressive alterations and unsuccessful treatments, as well as diagnosis at an advanced stage of the disease, contributed to the unfavorable prognosis.

\section{Conclusion}

The reported case is the first documented in donkeys and it shows that precocity and precision in obtaining the diagnosis of malignant neoplasia are fundamental for a favorable prognosis and establishment of the therapeutic plan. Tomographic examination is more accurate in identifying the extent of the alterations and impairment of the sinus region, compared to radiographic examination. Although uncommon, fibrosarcoma should be considered as a differential diagnosis for nasal cavity neoplasms in equines.

\section{References}

Alvarez, L. M. L., Neves, I. P., \& Tokarnia, C. H. (1973). Blastomas das vias respiratórias superiores em dois equinos. Pesquisa Agropecuária Brasileira, 8, 77-80.

Bass, K., Mochal-King, C. A., Cooley, A. J., \& Brinkman, E. (2017). Equine mandibular fibrosarcoma in two horses: clinical, diagnostic, and therapeutic considerations. Journal of Equine Veterinary Science, 48, 31-38. http:// dx.doi.org/10.1016/j.jevs.2016.08.017.

Bonfig, H., \& Ingenhorst, I. (1992). Surgical removal of a pedunculated uterine tumor in a donkey mare. Tierärztliche Praxis, 20(1), 65-68. PMid:1509483.

Boulton, C. H. (1985). Equine nasal cavity and paranasal sinus disease: a review of 85 cases. Journal of Equine Veterinary Science, 5(5), 268-275. http://dx.doi.org/10.1016/S0737-0806(85)80062-9.

Cissell, D. D., Wisner, E. R., Textor, J., Mohr, F. C., Scrivani, P. V., \& Théon, A. P. (2012). Computed tomographic appearance of equine sinonasal neoplasia. Veterinary Radiology \& Ultrasound, 53(3), 245-251. PMid:22211373.

Dixon, P. M., \& Head, K. W. (1999). Equine nasal and paranasal sinus tumours: part 2: a contribution of 28 case reports. Veterinary Journal, 157(3), 279-294. http://dx.doi.org/10.1053/tvjl.1999.0371. PMid:10328839.

El-Gendy, S. A. A., Alsafy, M. A. M., \& El Sharaby, A. A. (2014). Computed tomography and sectional anatomy of the head cavities in donkey (Equus asinus). Anatomical Science International, 89(3), 140-150. http://dx.doi. org/10.1007/s12565-013-0209-7. PMid:24129705.

Head, K. W., \& Dixon, P. M. (1999). Equine nasal and paranasal sinus tumours part 1: review of the literature and tumour classification. Veterinary Journal,157(3), 261-278. http://dx.doi.org/10.1053/tvjl.1998.0370. PMid:10328838.

Manso-Díaz, G., Dyson, S. J., Dennis, R., García-López, J. M., Biggi, M., García-Real, M. I., San Román, F., \& Taeymans, O. (2015). Magnetic resonance imaging characteristics of equine head disorders: 84 cases (2000-2013). Veterinary Radiology \& Ultrasound, 56(2), 176-187. http://dx.doi.org/10.1111/vru.12210. PMid:25139131.

Silva, A. P. C., Cassou, F., Andrade, B. S. C., Ramos, L. C. V. O., Paixão, T. A., Alves, G. E. S., \& Santos, R. L. (2012), Ossifying oronasal carcinoma in a horse. Brazilian Journal of Veterinary Pathology, 5, 128-132.

Solano, M., \& Brawer, R. S. (2004). CT of equine head: technical considerations, anatomical guide, and selected diseases. Clinical Techniques in Equine Practice, 3(4), 374-388. http://dx.doi.org/10.1053/j.ctep.2005.02.016. 
Tremaine, W. H., \& Dixon, P. M. (2001). A long-term study of 277 cases of equine sinonasal disease. Part 1: Details of horses, historical, clinical and ancillary diagnostic findings. Equine Veterinary Journal, 33(3), 274-282. http:// dx.doi.org/10.2746/042516401776249615. PMid:11352350.

Valentine, B. A. (2006). Survey of equine cutaneous neoplasia in the Pacific Northwest. Journal of Veterinary Diagnostic Investigation, 18(1), 123-126. http://dx.doi.org/10.1177/104063870601800121. PMid:16566271.

Veraa, S., Dijkman, R., Klein, W. R., \& Van den Belt, A. J. M. (2009). Computed tomography in the diagnosis of malignant sinonasal tumours in three horses. Equine Veterinary Education, 21(6), 284-288. http://dx.doi. org/10.2746/095777309X423031.

Witte, T. H., \& Perkins, J. D. (2011). Early diagnosis may hold the key to the succesful treatment of nasal and paranasal sinus neoplasia in the horse. Equine Veterinary Education, 23(9), 441-447. http://dx.doi. org/10.1111/j.2042-3292.2011.00251.x. 